\title{
Stage IIB Vaginal Cancer AJCC v8
}

National Cancer Institute

\section{Source}

National Cancer Institute. Stage IIB Vaginal Cancer A/CC v8. NCI Thesaurus. Code C139664.

Stage IIB includes: T2b, N0, M0. T2b: Tumor invading paravaginal tissues but not to pelvic wall, measuring more than $2.0 \mathrm{~cm}$. NO: No regional lymph node metastasis. M0: No distant metastasis. (AJCC 8th Ed.) 